\title{
第41回岡山外科会演題
}

\author{
時 略和 41 年 9 月 25 日（日） \\ 4. 前 10 恃 30 分一个後 3 师 \\ 所津山文化七ンター \\ 会長小坂二度見
}

一般演題

1. 真性脺臓囊腫の一摘出治験例

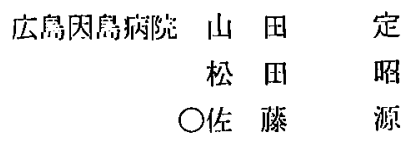

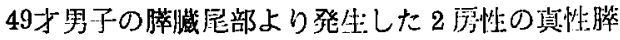

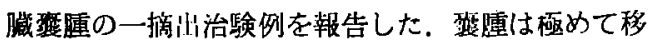
動性汇富み，大きさ $13 \times 7.5 \times 10 \mathrm{~cm}$ ひようたん非 を呈し，重量 $450 \mathrm{~g}$ であつた，酸燠哇には不灰化が みられ，眝溜液は黄任泥状波約 $300 \mathrm{ml}$ で, 総コレ ステリン $5640 \mathrm{mg} / \mathrm{dl}$ ，ジアスターゼ值 $2^{3}$ であつた.

\section{2. 綐隔洞腫瘍の経験}

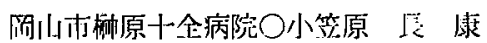

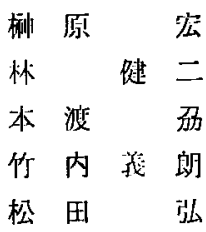

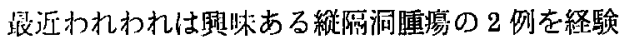
したので報告する。

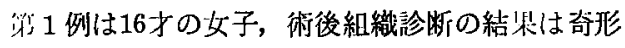
腫であつたが，畽演発見の動機が腫疰の胸膜への瘾 着による胸膜炎合併という点で診断上眮味あるもの であつた。

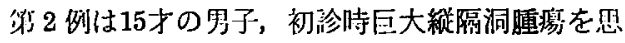
わすレ綵像であつたが，呵吸网耀その他の自覚症が

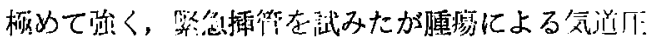

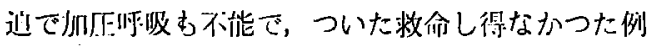
である,

翼問

网大㠺田外科稻田. 橴 痱例 1 の上うな例はめずらしいと思うが， X 線に
あられれた陰影は肋膜炎（渗出波）によるもの加， 财の炎症によるあのか。

答

楖 原宏

符 1 症例の Pleuritis は Tumor の Cyste の部か 破れておこしたものと考えている。

3. 舌下神経ノイリノームの 1 治験 例

$$
\begin{array}{r}
\text { 洞大䐘神経外科 三 宅 新太郎 } \\
\text { O士 井 章 弘 }
\end{array}
$$

舌下神経ノイリノームは非常に桥なふ筷患であつて， 1933年 de Martel 等の報告を最初として，現在まで 頭蓋内のもの9 例が報告されているか，そのうち手 術治験例は 2 例にすぎない。本例は右半例汇綵維性

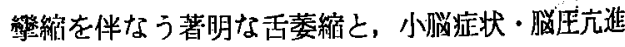
症状をきたして来院，後頭蓋窩開頭により一部倠胞 性の Neurinoma（約12g）を全摘出し全治退院し た. 頭蓋底撮影, 舌下神経管断層撮影, 逆行性頸郝 哌写などにつき報告した。

追加

阔大脳神経外科西本馀

頭蓋内ノイリノームでは聴神経ノイリノーム加王 倒的に多くほとんどすべてを占めている，本症は舌 下神経に生じた頭蓋内ノイリノームできわわてまれ な资患であり，手術治験例としては世界て 3 例目で あるので，とくに韩告した。

4. 虫体の摘出し得た Gnathostomi$\operatorname{asis} の$ 一例

$$
\begin{array}{r}
\text { 阔大田中外科朝 倉晃 } \\
\text { 竹 下 篤 } \\
\text { O武村志延 }
\end{array}
$$


香川県に在住する41才女性の䂓口虫症を経験し， その虫体を摘出することができた，患者は発病の約 5 年前に雷魚の料理をしたことがある. 約 3 年間に わたり，ほほ3ケ月に 1 回の割合で緊張感あるも無 消性の鲤脹が前腕加ら手掌, 手背にかけて移動性に 出没していた，入院時の検査所見で好酸球が11\%と 増加していた，左手母指球部が厙脹した際，切開を 加えて同部皮下より体長 $4 \mathrm{~mm}$ の有棘顎口虫を摘出 し，治㧪せしぬた。

\section{追加}

阔山赤十字病院 西 崎 太部志

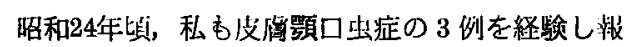
告した. 岡山県にも雷魚が棲息するようになつたの で，本症は時に外来化も訪れるのではないかと思う。 このような病気のあることを知つておく必要がある と思う。

\section{5, 大腿直筋短縮症の 1 例}

玉野三井病院 小川迲海 岡山済生会病院 $\bigcirc$ 江 口 寿栄夫

1 年10ケ月の男児で家族歴には異常なく, 既応歷 に大腿部への注射したととが $2 \sim 3$ 回ある. 満 1 才 頃より歩行をはじめてから，次第に右下股を柽度外 転外旋して少し引きずるように步き，また正坐がで きない，右大腿中央部前面淿皮層の伯みがあつて皮 下と瘾着し，䐂の屆曲制限があり，特有の尻上り現

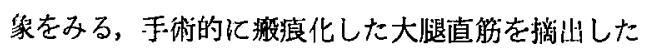
ら，僯の届曲制限はなくなつた，組織学的には後天 的な歷着による Fibrosis という榇断であつた。

追加

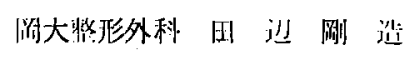

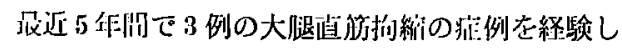

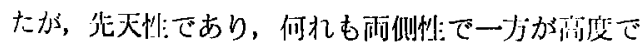
あつた場合である。

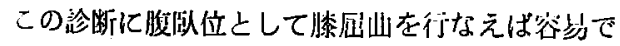
ある.

\section{6. 老人性坐骨神経痛の治療経験}

$$
\begin{aligned}
& \text { 倉敷中央病院 鶴 海 筧 治 } \\
& \text { ○丹羽権平 }
\end{aligned}
$$

高令者の坐骨神経演は青壮年者のそれと異なり，

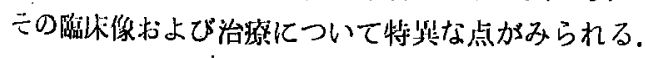

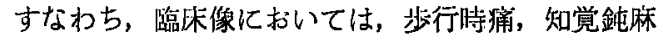
域が広算で神経筋任痛が著明なること，またとれら の症状と比べてラセーグ症候の程度が怪いととなど である、またいたずらに手術を急がずとあステロ イド硬膜内外注入, 温浴等の保存的療法がよく奏效 する．わ机わ机は臨休像において特異な症状を呈し ていてあやはり神経根性のもと考えている.

7. 足関節周囲の骨折一（2）腓骨単 独骨折

$$
\begin{aligned}
& \text { 阔大监形外科○的南 方 } \\
& \text { 前川啙 } \\
& \text { 臣場栤一 }
\end{aligned}
$$

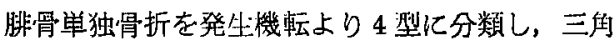
䕀帯，下前脛腓叔帯の提傷をみ抢とす危険性のある ととを指摘した。不安定性は, ストレス X一Pで判 定し，そのものには大退から趾までのギプス固が必 要だが，おしろ外科的修復を行なつた方がより良い と考える。

質問

倉敷中央病院 丹羽 椎 平

（1）强制位をとらせて，レ線像袟影を行なうとき， 舁者か疼痛を訴えると考えるが，如何に処理するか。

（2）尖足位ギプスを長期間巻いた後にこのための 障害が認められないか.

\section{答}

湤者

(1) Stress X-P について，曼㑺直後では徐々に Stress を加えてゆけば礳醉は不必要です，1時間以 上たつたものでは，腫脤・出血をきたし，少しの外

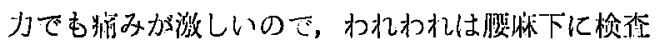
している.

（2）内父尖足位に刘して，5造目以後にこの不垃

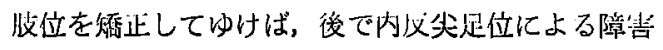
はありせん。

\section{8. パパイン軟高の使用経験}

\section{水島中央病院 橉 本 接 夫}

蛋白融解醉装パパインを主成分とする抗生物質含 有㳄度を，主として比較的新鮮な創傷飞使用した。 使用対象 50 症例中挫創を中心に約半数に明らかな效

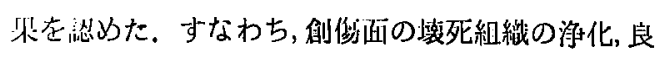


性肉芽の增殖，表皮化の促進がみられた。皮苚全層 の罗死，さらに筋膜・腱等の罗死したすのにあまり 有効でない. 受甥後 $2 \sim 3$ 日経過をみて, 使用の有 無を沃め, 使用期間は $2 \sim 4$ 日間で充分である. 長 期間使用していると創面より出血をみるようになる。 その前でトレックスガーゼに変えるのがよい，特に 副作用は認めなかつた。

9. 急性淋菌性汎発性腹膜炎の 1 例

閨山日赤病院○西 崎 太䛅志 佐藤昌平 杉本和夫

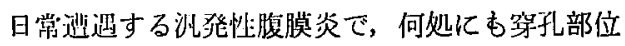
をみつけるこができないあのがある，淋菌性腹膜炎 は骨盤腹膜炎の形でくるのが殆んどであるが，汎発 性腹脱炎にまで発展するむのは極站て稆である。昨 年についで本年もまた一例を経験した。

術前診断および術中診断に困つたので，その特徴 と思われるものを述べ, 最近再び多発の傾向にある 性病に対して外科医はある程度の注意を払う必要が あることを強調した。

10. 小腸平滑筋腫の一例

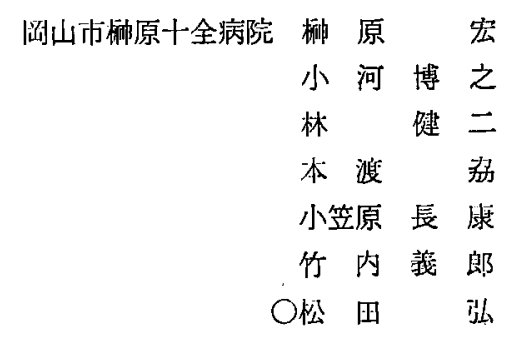

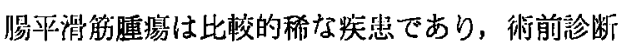
む困難であるため開腹時に偶然に発見されたり，他 の䓂断で開腹されることが多い，われわれは最近経

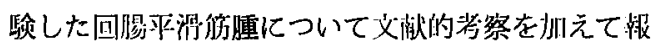

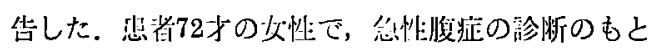
に緊总手術を行なつたものて，回腸終末部より口侧 $2 \mathrm{~m}$ 江腫瘤を涊好た。腫瘤は管内外性に発肖し, 一 部增死状になり穿孔がみられ，そのため汹発性腹脱 炎を起していた。

11. 瘢痕性食道狭窄症に合併した食 道異物の一治験例

岡大秒时外科 勝 村 㙂

$$
\begin{array}{cc}
\text { 土肥俊之 } \\
\text { ○源 佑一郎 }
\end{array}
$$

雚下障害，胸骨後部疼痛および頻回な嘔吐を主訴 とする56才の女性の洀狼性食道狭窄に合併した食道 異物症の一例に対し，食道異物摘出ならびに食道形 成術を施行し治瘜せしふた．本例は約 30 年前比苛性 カリを服用し，第 2 ・第 6 および第 9 腧椎の高さの 食道にそれぞれ中心性狭窄を米していた，食道異物 はコンブあるいはアラメの幹であつた。本症の一例 を報告し，岡大第 2 外科教室における過去 10 年間の 本症の 7 例とと.屯に文献的考察を加えた。

追加

岡大砂的外科 勝 村 这 齿

この患者は約20年前に産後の経過が悪くて自殺の 目的で笴性カリを服用し，以後食道狄窄のため非常 な時間をかけて普道食掑取をしていた，とてろが御 主人が脸卒中で最近倒れ自宅療養をしていますので よく手招きで奥さんである患者を呼ばれることが多 くなりました。そこの日も朝本人が茶漬を食べていた ところ急に御主人に呼ばれまして，あわててロの中 に入れていた奈良清を吞み込んだといいます。異物 は奈良清かと思つたのですが，取り出したものはゴ ボウ状でした。植物形態学教室で検査の結果ではつ ラメ、コンブの幹ということでした。食道再建術を 施行する必要があるかと思つたのでか，開胸してみ ます之食道筋層は全く正常で粘膜のみが数ヶ所輸状 亿狄窄を米たしていました，洀蓈性食道狄窄む案外， われわれの様な手術方法の適応があるものが多いの ではないか上考えます。

12. 閉鎖孔へルニア嵌頓によるイレ ウスの一例

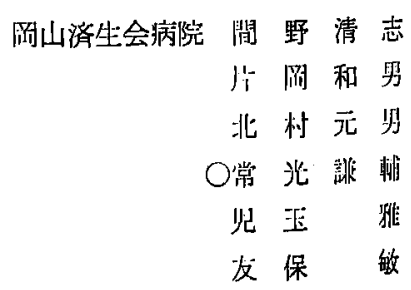

閉銷孔ヘルニア嵌頓によるイレウスの1例を報告 し，文献的考察を加えた。症例は77才の女で，1遏 間前より左下肢痛, 腹痛あり，3 日前より嘔吐が始 つた。腸閉塞として手術す. 回腸末端より200 cm口㑡 の渴管が約 $10 \mathrm{~cm}$ 左閉銷孔に炭顿し，壊死飞陷つて 
いた，腸管切除，端々㽗合を行ない，ヘルニア門を 結節縫合で閉銷す，術後経過は良好である.

13. 平野外科病院における早期胃癌 津山秗平野外科淀院 平 野 仁之 ○平 野 義 郎

昭和37年10月より昭和 41 年 8 月末までの 3 年11ケ 月に，当院での胃切除は 211 例，そのうち胃虞は50 例 (23.7\%). 第 3 回胃癌研究会の早期胃癌の基準 に一政するすの 5 例について, 各症例のレ線所見， 切除標本肉眼所見, 病理組織学的所見等を供覧し, 私共外科医は今後之あ内科医之協力し, 早期胃嵒の 診断治療に努力すると共に，その予後を追求すべき 責任のあることを強調した。

14. 術中胃細胞診について

$$
\begin{array}{rr}
\text { 津山中央病院 額 } & \text { 田須賀天 } \\
\text { O河 原 } & \text { 徽 }
\end{array}
$$

最近，胃癌猃断率は著しく向上しているが，それ でもなお診断できない症例も少なくないが，われわ れは術中細胞診を行ない, 病巣の良性, 悪性の判定 を行なつて，より適切な手術を行なつているので， 2 例の症例をあげてその結果を報告する。
瞄問

津山市平野外科病院 平 野 保 之

術中細胞診というのは切除胃を切開して, direct smear をとるのか，胃切開を行なつて切除前に採取 するのか.

答

$$
\begin{aligned}
& \text { 細胞晾により癌細胞を発見したら，2群リンパ節 } \\
& \text { まで除去する，術中大弯側にて切開し細胞診を行な }
\end{aligned}
$$
j.

\section{会長講演}

心疾患之啝酔

凧场酰科 小䛀 二度見

\section{㩍朝譲演}

1. ウェスターン・リザーヴ大学形 成外科留学の感想

岡山斎坐会病院 谷太三郎

2. 米国の整形外科

椆大整形外科児玉 俊夫

\section{第42回 岡山外科会演題}

$$
\begin{aligned}
& \text { 時 昭和 } 42 \text { 年 } 2 \text { 月 } 18 \text { 日 (土) } \\
& \text { 午後 } 1 \text { 特一午後 } 5 \text { 時 } 30 \text { 分 } \\
& \text { 所風山大学医学部第 } 1 \text { 購義空 } \\
& \text { 公烄 小坂 二 度 見 }
\end{aligned}
$$

\section{一般演題}

\section{1. 重複胆穣の一例}

$$
\begin{aligned}
& \text { 阔大田中外科朝食芫 } \\
& \text { ○山本三郎 }
\end{aligned}
$$

症例は27才の女性で昭和41年10月 1 日，胆裹炎症 状で胆震剔出術をうけた。手術に際して胆衰が三つ 認められ，そのうち二つの胆嚄は Boyden, Gross 等 のいう Y-shaped type の double gall bladder の形 をとつて扔り，他の一つはこれ篎上は独立して総胆
简に阴匹しており，作せて triple gall biadder を 非成している，現住まで triple gall bladder の证 例は，1958年 Skielboe の1例がみられるだけで,

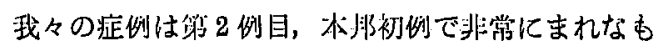
のである.

\section{2. 気管腺腫の一例}

$$
\begin{array}{r}
\text { 岡大砂田外科 河 合 進 } \\
\text { O藤 谷 良 幸 }
\end{array}
$$

私たちは気管腺尰の 1 例を経験しましたので多少 